\title{
Relationship Between the Built Environment and the Location Choice of High-Tech Firms: Evidence from the Pearl River Delta
}

\author{
Kangmin $W u^{1,2,3}{ }^{-}$, Yang Wang ${ }^{2, *}$, Yuyao $\mathrm{Ye}^{2, *}$, Hongou Zhang ${ }^{2}$ and Guangqing Huang ${ }^{2}$ \\ 1 Guangzhou Institute of Geochemistry, Chinese Academy of Science, Guangzhou 510640, China \\ 2 Guangdong Open Laboratory of Geospatial Information Technology and Application, Guangzhou Institute \\ of Geography, Guangzhou 510070, China \\ 3 College of Resources and Environment, University of Chinese Academy of Science, Beijing 100049, China \\ * Correspondence: wyxkwy@163.com (Y.W.); yeyuyao@gdas.ac.cn (Y.Y.); Tel./Fax: +86-20-8768-5006 (Y.W.)
}

Received: 10 June 2019; Accepted: 2 July 2019; Published: 5 July 2019

\begin{abstract}
With the transition in the regional development discourse to knowledge- and innovation-based economics, the cultivation of innovation capacity has gained importance as an initiative to enhance regional sustainability and has emerged as a policy goal. An understanding of the formation of innovation clusters is critical to the cultivation of regional innovation capabilities. Except for the location and regional development conditions' factors, researchers emphasize a built environment's role in the formation of innovation clusters. Based on the spatial database of 12,516 high-tech firms in 2017 in the Pearl River Delta (PRD), this study developed a conceptual framework for the built environment. The framework comprises living, service, perceptual, industrial, and physical aspects. The direction and intensity of the correlation between built environment factors and high-tech firms are discussed using the spatial regression model and geographical detector (GD) technique. The results show a highly concentrated spatial distribution pattern of high-tech firms in the PRD. A significant county-level spatial autocorrelation is revealed through Moran's I. According to the model, we determine the positive impacts of technology support, transport infrastructure, and living service levels on the agglomeration of high-tech firms as well as the negative impact of the public service level. The GD's result demonstrates different levels of impact intensity of built environmental factors. We argue that a comprehensive understanding of the influence of built environment factors on innovation agglomeration will help policymakers develop targeted policies to foster local innovation capabilities and promote sustainable regional development.
\end{abstract}

Keywords: innovation; high-tech firms; built environment; Pearl River Delta

\section{Introduction}

The "Transforming our world: The 2030 Agenda for Sustainable Development," which proposed 17 sustainable development goals (SDG), was released at the 2015 United Nations Development Summit [1]. Among them, SDG 9 defined the relationship between "innovation" and "sustainability." Referred to as "Industry, Innovation and Infrastructure," this goal states that scientific and technological progress is critical to achieving environmental goals. In other words, technological innovation is key to triggering industrialization and, in turn, facilitating development. It was proposed to strengthen scientific research and enhance technological capabilities in all countries, especially developing countries, and, in turn, achieve industrial diversification and increase the added value of goods [2]. Therefore, understanding the mechanism behind location selection for developing innovative clusters is an important measure of capacity building for sustainable regional development [3-5]. 
In the past decade, the "innovation" discourse and knowledge for explaining the competitiveness of regional economic systems have captured the interest of academics and policymakers [6]. Innovation is widely regarded as one of the main drivers of sustainable economic and regional growth. This becomes evident through the European Union's (EU's) biggest technological innovation program called "Horizon 2020," budgeted at 77 billion euros. Improving regional innovation capability has been considered an important means of enhancing regional economic competitiveness [7-10]. In this context, the study considers the case of the Pearl River Delta (PRD). Since the rise of the PRD in the late 1970s, the process of developing this region has been conceptualized in the literature as a process of strategic coupling of regional assets with the global economy [11,12]. While engaging in the global production network (GPN) is considered crucial for the industrialization of the PRD, the export-oriented development model is criticized by scholars. Identifying new development models is critical to the sustainable growth of the PRD. In this regard, "innovation" is one of the main development discourses. The research and development (R\&D) funds accounted for $2.13 \%$ of China's gross domestic product (GDP) in 2017, rising from only $1.09 \%$ in 2001. For the PRD, however, this value was $2.94 \%$ in 2017.

Considering the significance of innovation, the theory of entrepreneurship believes that new companies created by entrepreneurs can bring "creative destruction," which is the source of innovation and economic growth [13,14]. Based on Schumpeter's study, economists developed theories of entrepreneurship to demonstrate the relationship between innovation activities and economic growth $[15,16]$. Additionally, the geographers introduced the concept of space in the study of entrepreneurship, which focuses on the spatial agglomeration and ecosystem organization of innovation activities [17-19]. The role of high-tech firms in driving innovation and economic growth is confirmed by many studies. Based on the empirical research on innovation geography, high-tech firms were found to be more concentrated in a few regions than firms in the manufacturing industry $[20,21]$. The mechanisms involved in selecting their locations are also different from those employed for traditional manufacturing companies. The distribution of high-tech firms is closely related to local innovation status, and the employees of high-tech firms are mainly comprised of workers with high-quality knowledge.. These features cause high-tech firms to focus more on the local built environment $[22,23]$.

The selection of location for high-tech firms is affected by several complex factors. Specifically, the mechanisms for selecting the target location are related to both the mechanism of how innovations are generated, and the activity area selected by the company. A wide range of theories were developed for analyzing these two aspects. Currently, the main paradigms used to explain the agglomeration of innovation activities and the generation of innovations are agglomeration and diversity [24]. These two paradigms focus on two main mechanisms associated with innovation activities and firm agglomeration, that is, Marshall agglomeration and Jacobs diversity [25]. Marshall agglomeration mainly emphasizes the spatial agglomeration of the same type of economic activity, while Jacobs diversity focuses on clusters of firms from different industries and, particularly, the knowledge spillovers brought by diversification. Vast literature, focusing on the distribution of innovation firms, aims to demonstrate the influence of several factors, including the different types of specialization, agglomeration, and diversification, on the choice of innovation locations [19,26,27].

From a theoretical dimension, the theories of location choice for enterprises can be broadly classified into the following three perspectives: behaviorism, neoclassicism, and institutionalism [28,29]. The theory based on behaviorism emphasizes the internal factors of firms such as factors pertaining to the firms' heterogeneity, including the product, scale, capital structure of the firms, and behavior of the entrepreneur [30-32]. Among them, corporate governance and firm size were identified as key factors. Governance mechanisms, such as market competition, mutual monitoring among the executives, Chief Executive Officer (CEO) tournament, and inside debt, play a crucial role in firm behavior. Giroud and Mueller found that in noncompetitive industries firms with weak governance exhibit weak operating performance [33]. Li paid close attention to the number two executive and found that mutual monitoring significantly improves firm value [34]. Jeffrey found that firm performance and risk increase in the external pay gap [35]. Li proposed an index that reflects the credit risk-adjusted 
level of inside debt; he found that managers are concerned with the risk-adjusted value of their inside debt [36]. Dang found that firm size has a significant influence on firm performance. A large number of studies reveal that internal factors profoundly influence a firm's behavior, including the way they choose their location [37]. However, neoclassicism and institutionalism focus more on external factors, such as the urban economic development level, human capital, location advantages, innovation and institutional environments, and the quality of the location [9,38-41].

The literature on high-tech firms' location choice and innovation emphasizes the role of built environment factors. A study by Shima showed that regional compactness has a significant positive impact on innovative firms and regional innovation capacity [42,43]. Li found that accessibility can significantly affect the location choice for high-tech firms [29]. The research by Bettencourt demonstrated a super-linear relationship between the number of patent applications and the city size [44]. Glaeser found that the differences in the spatial distribution of entrepreneurship can be explained by the differences in human capital and industry structure [45]. Kiuru also found a strong spatial coupling between the innovation clusters and the high-level human capital communities in large cities [46]. Feldman and Florida examined the factors affecting an innovation location, based on commercial innovation products; they found that innovation is related to "technical infrastructure" and the level of infrastructure facilities and business activities in the local region [20]. Lawton inspected the location preferences of the "creative class" in Dublin and found that housing cost, accessibility, and living environment are the three most important factors affecting the location choice of knowledge workers [47]. Morais assessed the urban quality of life of European cities from the perspective of human capital. He found that the quality of life, such as the quantity and quality of amenities, significantly influenced the location choice of highly educated workers [48]. Esmaeilpoorarabi discussed the relationship between location quality and innovation clusters by constructing a conceptual framework containing the following five dimensions: context, form, function, ambiance, and image. His study revealed that traditional hard factors cannot solely contribute toward the formation of an innovation cluster. Instead, a human-oriented design for an urban structure that respects the natural and human environments is also crucial to the formation of an innovative agglomeration [23].

However, in studies on the location choice and the agglomeration of innovation, built environment was often conceptualized as part of the location factors. For example, the overall impact factor framework included the infrastructure [22], accessibility [29], and technology support levels [20]. Such an approach fails to provide a systematic analysis of the built environment. Due to the difference between high-tech firms and traditional companies, high-tech firms consider some distinctive factors when selecting their locations. For example, the requirements for a local innovation environment would be higher. The knowledge workers and creative class highly prefer the living environment, including the natural environment, public service environment, and convenient lifestyle [22,49]. Simultaneously, since the high-tech firms are also closely linked to the local innovation environment, these firms may show a strong dependence on the level of local science and technology support [50,51]. Therefore, the built environment may play a more crucial role in determining the location for innovative activities. On the other hand, in terms of methodology, existing research usually uses regression analysis to examine the relationship between built environment factors and innovation distribution. However, the regression analysis method can only statistically analyze the positive and negative relationships and significance between factors and innovation distribution; there is limited focus and discussion on the spatial autocorrelation of innovation distribution, and it cannot accurately identify the intensity of the impact on the spatial distribution of innovation.

While existing literature addressed how different built environment factors are related to the distribution of innovation, a systematic concept framework of built environment based on the perspective of innovation has not yet been proposed. Additionally, the intensity of the impact of built environment factors on innovation distribution and the heterogeneity between these factors are under-investigated. This empirical study aims to address this gap by examining the relationship between built environment and innovation distribution and further explore the impact of the significant 
factors. By considering the case of the PRD, a more systematic framework of built environment factors is established in this study. We examined the direction and intensity of impacts of the built environment on the agglomeration and location choices of high-tech firms, using a combination of spatial regression and the geographical detector (GD) technique. The spatial regression method also considers the spatial correlation of the innovation distribution; it can more accurately reveal the relationship between the factor and the innovation distribution than the Ordinary Least Square(OLS) model. The GD examines the differences between the spatial distribution of built environment factors and innovation, and thus it can reveal the impact intensity of the factors on the distribution of innovation.

The remaining section of the paper is organized as follows. The Section 2 introduces the conceptual framework, research data, and main methods of this study; the Section 3 discusses the research results, focusing on the spatial distribution of high-tech enterprises in the PRD and the impact of built environment on the location choice. The Section 4 presents the main conclusions drawn from this study.

\section{Materials and Methods}

\subsection{Study Area}

The PRD was selected as the research area; it comprises Guangzhou, Shenzhen, Dongguan, Foshan, Zhuhai, Huizhou (excluding Longmen county), Zhongshan, Jiangmen, and Zhaoqin (excluding Huaiji, Deqing, Guangning, and Fengkai) (Figure 1). The total area of this region is $41,711 \mathrm{~km}^{2}$. The resident population was $59,126,800$ in 2017 . From the mid- to late-1970s, foreign capital significantly promoted the industrialization of the PRD, which transformed it into a "world factory" in the global economy. This region witnessed the strategic coupling of production factors (e.g., cheap land and labor), with leading firms in the GPN [11,12]. Although the significance of engaging in the GPN for promoting industrialization and urbanization of the PRD is recognized in the current literature, such a development model is also criticized heavily [8]. In 2008, the Central Government of China clearly stated in the "Outline of the Reform and Development Plan of the Pearl River Delta Region (2008-2020)" that the PRD suffers from multiple issues, including a low industrial level, low value-added products, inadequate innovation ability, and weak overall competitiveness. Additionally, the PRD faces a huge crisis of sustainable development. In the same year, the Guangdong Provincial Government proposed the "Empty the cage for Birds" strategy to promote industrial upgradation of the PRD and to free up space for high-tech industries with high added values by shifting the local low-end labor-intensive industries. In 2019, the Central Government of China issued "The development plan for Guangdong-Hong Kong-Macao Greater Bay Area." This plan clearly proposed the development strategy of transforming the PRD, Hong Kong, and Macao into an international science and technology innovation center. In other words, "innovation-driven" emerged as one of the core concepts for promoting development of the PRD agglomeration. 


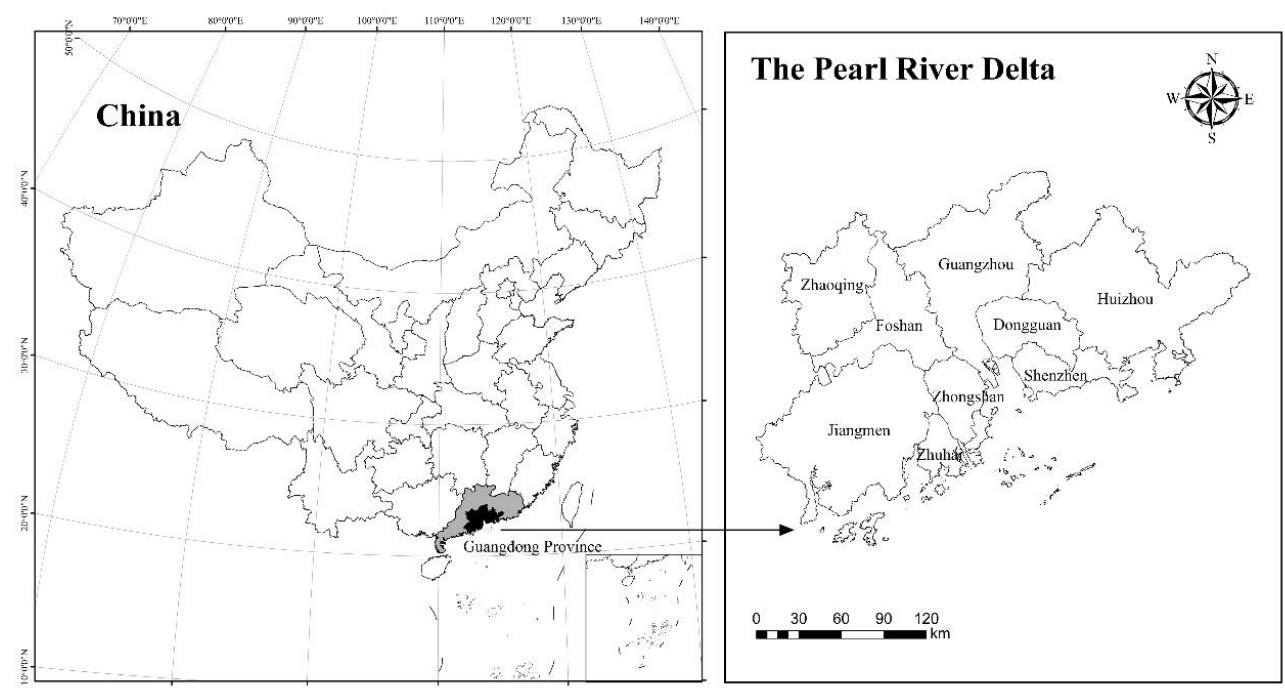

Figure 1. Study area.

\subsection{Conceptual Framework}

This study aims to determine the impact of built environment on high-tech firms quantitatively. To this end, we designed a conceptual framework (Figure 2). The analysis procedure is as follows. With data from 97 counties in the PRD (since Dongguan and Zhongshan have no county-level administrative units, their town-level administrative units were used in this study to perform the regression analysis), we first determined the significance and impact direction of the factors of built environment and urban fundamentals using the spatial regression model. Based on these results, we further determined the impact magnitude of significant factors using the geographical detector technique. Finally, the results from the study were rationalized to explain how the built environment affects the location choice and agglomeration of high-tech firms.

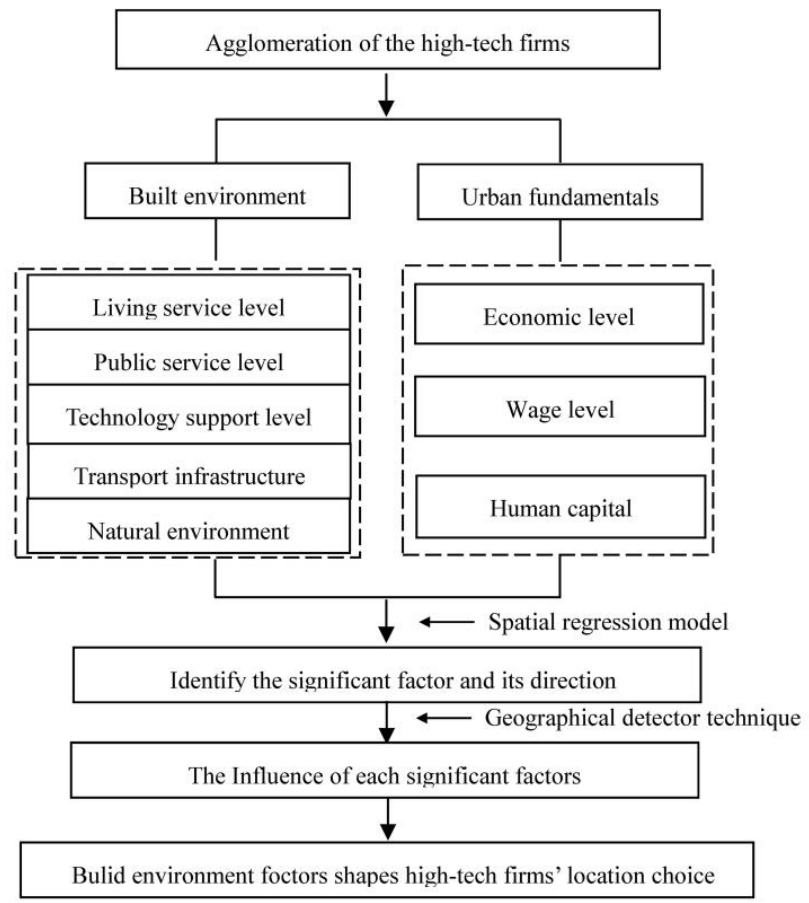

Figure 2. Conceptual framework. 
The concept of built environment usually includes multiple aspects such as the local physical environment and natural environment. The meaning of built environment is also different under different academic contexts. Based on the understanding of location choice of high-tech firms, which is derived from the institutionalism and neoclassical perspectives, and combining it with a focus on the built environment from the innovation perspective, this study proposed a multidimensional model as a framework to conceptualize the built environment more systematically (Figure 3). In our conceptual framework, we highlighted built environment factors relevant to innovation in terms of the following five aspects: living, service, perceptual, industrial and physical aspects. Subsequently, five indicators were selected corresponding to these five aspects, which include living service, public service, technology support, transport infrastructure, and natural environmental levels. Simultaneously, we selected several factors as control variables to characterize urban fundamentals. These factors include economic and wage levels and human capital. The statistical description of the variables and the expected direction of influence are summarized in Table 1.

- $\quad$ Living service level (LSL): LSL increases convenience, and hence is considered an important aspect of place quality. Many empirical studies show that location quality plays an important role in attracting knowledge industries and high-quality talents and in forming innovative agglomeration [22,52]. The LSL is represented by the density of basic living services (supermarkets and convenience stores) in each county. The role of the LSL is hypothesized to be positive.

- Public service level (PSL): PSL is a core factor for determining the attractiveness and competitiveness of a city. Knowledge workers will consider the lifestyle and PSL of a place when choosing a workplace [22,23]. In this study, PSL is represented by the density of the basic PSLs (primary school, middle school, hospital, museum, and stadiums) in each county. The role of PSL is hypothesized to be positive.

- Technology support level (TSL): Universities and research institutions are hubs for innovative talents and resources; these bodies produce all kinds of radical innovations [53,54]. In this study, TSL is represented by the density of research institutions (main universities and research institutes) in each county. The role of the TSL is hypothesized to be positive.

- Transport infrastructure level (TIL): TIL has always been an important consideration for the location choice of enterprises. Several studies confirmed that a good transportation infrastructure condition and high level of accessibility can significantly reduce the operating costs of enterprises and promote their agglomeration $[29,30]$. In this study, TIL is represented by the density of the road network in each county. The role of the TIL is hypothesized to be positive.

- Natural environmental level (NEL): Existing studies have shown a close relationship between the urban environmental condition and the agglomeration of creative classes in cities [55]. The natural environmental condition is an important factor affecting the migration of high-quality talents, who are considered one among the innovation sources. In this study, the $\mathrm{PM}_{2.5}$ (fine particulate matter) value was used to represent the natural environmental level of each county. We obtained the $\mathrm{PM}_{2.5}$ monitoring data (including data from 56 monitoring stations in the PRD), released by the Ministry of Environmental Protection of China in 2017. Subsequently, we selected the $\mathrm{PM}_{2.5}$ monitoring data, which was recorded at 12:00 am (365 days in 2017) and obtained the average monitoring value of $\mathrm{PM}_{2.5}$ for each monitoring station in 2017 (12:00 am). Finally, the $\mathrm{PM}_{2.5}$ average value of each county was obtained by the inverse distance weighing (IDW) interpolation method. The role of the NEL is hypothesized to be negative. 


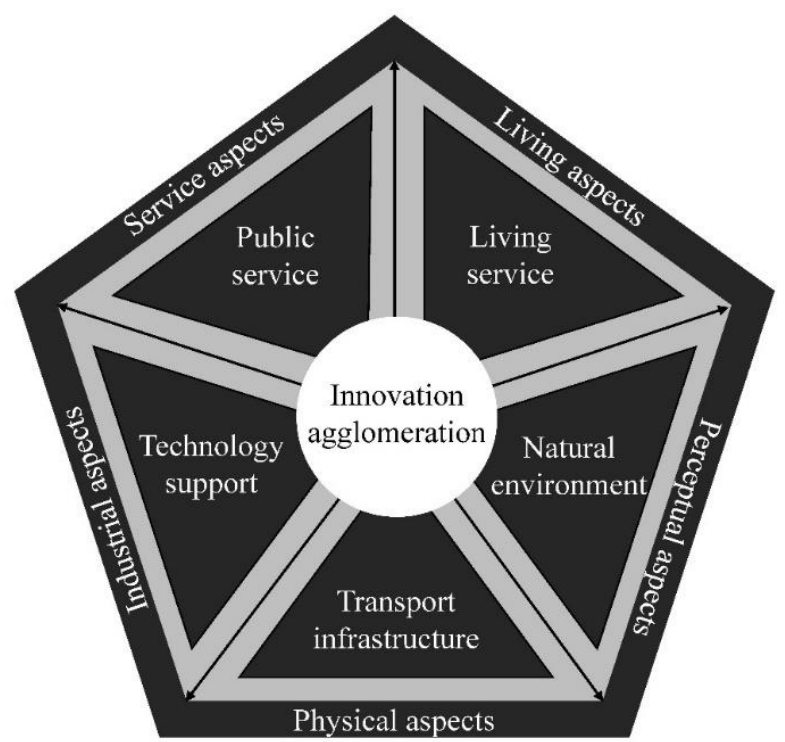

Figure 3. Conceptual framework of built environment in innovation agglomeration.

Table 1. Definition and descriptions of the variables.

\begin{tabular}{|c|c|c|c|c|c|c|c|}
\hline Variables & Definition & Symbol & $\begin{array}{c}\text { Expected } \\
\text { Directions }\end{array}$ & Min & Max & Mean & Std.Dev. \\
\hline Dependent Variable & $\begin{array}{l}\text { Density of high-tech enterprises } \\
\left(\text { activities } / \mathrm{km}^{2}\right)\end{array}$ & Y & & 0.00 & 5.70 & 0.80 & 1.01 \\
\hline \multicolumn{8}{|c|}{ Explanatory Variables-Built environment } \\
\hline Living service level & $\begin{array}{l}\text { Density of major living service facilities } \\
\text { (supermarkets, convenience stores) } \\
\text { (activities } / \mathrm{km}^{2} \text { ) }\end{array}$ & LSL & + & 0.23 & 58.59 & 13.79 & 13.50 \\
\hline Public service level & $\begin{array}{l}\text { Density of major public service facilities } \\
\text { (primary schools, secondary schools, } \\
\text { general hospitals, museums, general } \\
\text { gymnasiums) (activities } / \mathrm{km}^{2} \text { ) }\end{array}$ & PSL & + & 0.05 & 6.44 & 0.63 & 0.94 \\
\hline $\begin{array}{c}\text { Technology support } \\
\text { level }\end{array}$ & $\begin{array}{l}\text { Density of major universities and research } \\
\text { institutes (activities } / \mathrm{km}^{2} \text { ) }\end{array}$ & TSL & + & 0.00 & 11.85 & 0.45 & 1.44 \\
\hline $\begin{array}{c}\text { Transport } \\
\text { infrastructure level }\end{array}$ & $\begin{array}{l}\text { Density of the road network of each } \\
\text { county }\left(\mathrm{m} / \mathrm{km}^{2}\right)\end{array}$ & TIL & + & 0.99 & 19.93 & 6.40 & 4.04 \\
\hline $\begin{array}{c}\text { Natural } \\
\text { environmental level }\end{array}$ & $\begin{array}{l}\text { PM2.5 detection value (microgram/cubic } \\
\text { meter) }\end{array}$ & NEL & - & 25.82 & 45.81 & 36.18 & 3.43 \\
\hline \multicolumn{8}{|c|}{ Explanatory Variables_-Urban fundamentals } \\
\hline Economic level & $\begin{array}{l}\text { Per capita gross domestic product (GDP, } \\
\text { yuan) }\end{array}$ & EL & + & $35,920.96$ & $324,165.33$ & $109,261.68$ & $61,128.34$ \\
\hline Wage level & $\begin{array}{l}\text { Average salary of urban employee } \\
\text { (yuan/person) }\end{array}$ & WL & + & $57,394.00$ & $128,508.00$ & $70,496.04$ & $14,527.38$ \\
\hline Human capital & $\begin{array}{l}\text { Proportion of population with high } \\
\text { education (undergraduate and above) (\%) }\end{array}$ & $\mathrm{HC}$ & + & 0.01 & 0.26 & 0.06 & 0.04 \\
\hline
\end{tabular}

The factors used as control variables to characterize urban fundamentals are selected based on the following reasons:

- Economic level (EL): Cities with higher economic development levels exhibit greater vitality and attract more talent. Existing studies have shown that a city is an innovation machine [18] and gathering multiple innovative subjects better facilitates innovation generation. In this study, the EL is represented by the GDP per capita. The role of the EL is hypothesized to be positive.

- Wage level (WL): Labor cost is an important consideration for the location choice of firms. Previous studies have shown that local labor costs have a significant negative impact on the location of manufacturing companies [30]. However, few studies explored the mechanism of how local labor costs affect the distribution of high-tech firms. There are structural differences between the employees in high-tech firms and manufacturing companies. Therefore, the sensitivity to the labor force may be different. In this study, WL is represented by the average salary of the residents in each county. The role of WL is hypothesized to be positive. 
- Human capital (HC): $\mathrm{HC}$ is an important driving force for the development of regional innovation systems. Many studies have shown that there is a robust relationship between HC and the spatial agglomeration of innovation in cities [46,56]. In this study, the highly educated population (with a bachelor's degree or above) is used to represent HC, which is hypothesized to be positive.

\subsection{Data and Data Sources}

The high-tech firms' datasets were collected from the list of high-tech firms that was announced by the Guangdong Provincial Department of Science and Technology. Firms' latitude and longitude coordinates were obtained through the application programming interface of the Baidu map, using the geocoding technology. Afterwards, we performed a coordinate transformation and eliminated the outliers to construct the spatial database. This database covered a total of 12,516 firms in the PRD in 2017 (Figure 4). It is important to mention that the research objects targeted in this study mainly comprise small- and medium-sized technology enterprises (SMEs). Due to the current recognition rules concerning China's "high-tech enterprises," small-sized and small profit-making enterprises (小 型微利企业) that meet the requirements will be eligible for a $20 \%$ corporate income tax exemption, and high-tech enterprises reliant on state support will benefit from a $15 \%$ corporate income tax exemption. This provision has prompted a keenness in many conforming SMEs to be included in the list of high-tech firms to reduce operating costs. Therefore, most of the identified high-tech firms are newly established SMEs, and these enterprises also represent the latest technological developments in the region [43]. During 2018-2019, we interviewed relevant personnel from the Guangdong Provincial Science and Technology Department, as part of the research for the "Guangdong Province Comprehensive Innovation Reform Assessment" project. They confirmed that the high-tech enterprise directory mainly comprises small- and medium-sized science and technology enterprises.

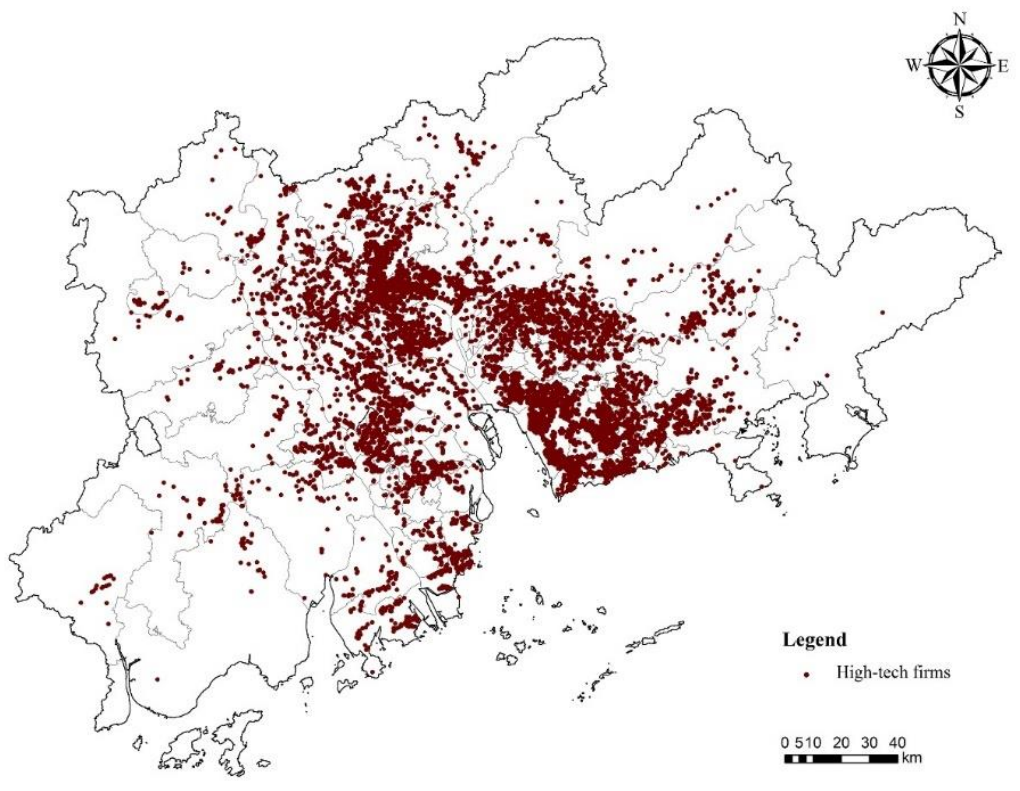

Figure 4. High-tech firms in Pearl River Delta.

The data on the eight indicators used in this study are taken from the following sources: the LSL, PSL, and TSL data are sourced from the 2017 Guangdong Province Point of Interest (POI) database; the TIL data is derived from the PRD Road Network Vector Database; the NEL data is obtained from $\mathrm{PM}_{2.5}$ monitoring data, released by the Ministry of Environmental Protection of China; the EL and WL data are taken from the 2018 Guangdong Statistical Yearbook; and the HC data is extracted from the 1\% Population Sample Survey Data of Guangdong in 2015. 


\subsection{Methods}

\subsubsection{Kernel Density Estimation}

The kernel density estimation (KDE) method is a kind of nonparametric estimation method. The advantage of the KDE method is that it can be applied to any location in the study area for estimating planar hotspots [30,57]. The KDE function can estimate the density around the sampled firms, based on the density of samples within a unit grid, and subsequently, produce a smooth surface. This surface can reflect the hotspot distribution associated with the spatial pattern of firms. The KDE function is given by:

$$
\lambda(\mathrm{i})=\sum_{i=1}^{n} \frac{1}{\pi r^{2}} \varphi\left(\frac{d_{j i}}{r}\right)
$$

Here, $\lambda(i)$ is the estimated value of the kernel density (KD), $r$ is the bandwidth (i.e., the search radius for the KD function), $n$ is the sampling number of firms, $d_{j i}$ is the distance between the firm's sample point $j$ and $i$, and $\varphi$ is the weight for the distance.

\subsubsection{Regression Analysis}

Most studies employ the OLS regression to explore the potential impact mechanism of firm location. However, the OLS model neglects the spatial autocorrelation of firm distribution, and it may seriously bias the results [58,59]. Owing to the development of spatial measurement models, the spatial regression model can further consider the spatial correlation of geographical phenomena, and therefore reveal the distribution mechanism more accurately. In this study, both the OLS and spatial regression models were used simultaneously to investigate the mechanisms influencing the distribution of high-tech firms. The method that can most accurately reflect the distribution mechanism of high-tech enterprises falls between these two approaches [59].

OLS is a linear model that is widely used to explore the linear correlation between dependent and independent variables. The presumption of the OLS model is that the variables are independent. In this model, the spatial information of the variables is ignored. The expression of the OLS model is given by:

$$
y_{s}=\lambda \mathrm{x}_{\mathrm{si}}+\varepsilon
$$

Here, $y_{s}$ is the dependent variable (the density of high-tech firms); $s=1, \ldots, 97$ represents the 97 counties in the PRD; $x_{s i}$ is the independent variable $(i=1 \sim 8)$, which includes the estimated parameter of the regression model LSL, PSL, TSL, TIL, NEL, EL, WL, and HC; $\lambda$ is the estimated parameter of the regression model; and $\varepsilon$ is the error of the model.

Spatial regression models include spatial error regression (SEM) and spatial lag regression (SLM). SLM mainly focuses on the spatial spillover of variables. Its expression is given by:

$$
y_{s}=\rho \sum_{s=1}^{n} W_{s} y_{s}+\lambda x_{s i}+\varepsilon
$$

Here, $W_{s}$ represents the spatial weight matrix; $\varepsilon$ is the error of the model; $\rho$ represents the spatial autocorrelation coefficient. SEM is mainly used to deal with the spatial dependence of error terms. The expression of SEM is given by:

$$
y_{s}=\lambda x_{s i}+\varepsilon, \varepsilon=\rho \sum_{j=1}^{n} W_{s} \varepsilon_{s}+\varepsilon
$$

Here $\rho$ represents the spatial autocorrelation coefficient, and $\varepsilon$ represents the random error term. 


\subsubsection{Geographical Detector Technique}

The geographical detector (GD) technique developed by Wang in 2010 is used for studying the relationship between disease risk and geographical influence factors [60]. The advantage of the GD technique is that there are less hypothesis constraints; it can also be applied to both categorical and continuous variables. Unlike the traditional regression analysis, the GD technique reveals the influence of the independent variables by examining the differences in the spatial distribution of the dependent and independent variables. This method can more accurately reveal the intensity of the impact of built environmental factors on the spatial distribution of innovation [61,62].

The core idea of using the GD method to explore the impact intensity of built environment factors is explained as follows. Since the built environment factor exhibits different characteristics in the spatial domain, if a significant consistency is found between a specific factor and the spatial agglomeration of high-tech firms, then such built environment factor would significantly influence the distribution of firms. Additionally, the geographic detection intensity of the influencing factor can be expressed by:

$$
\mathrm{q}=1-\frac{1}{\mathrm{n} \sigma^{2}} \sum_{i=1}^{m} n_{i} \sigma_{\mathrm{i}}^{2}
$$

Here, $q$ is the detection intensity of the influencing factor, $m$ denotes the number of classifications of independent variables (in this study, the independent variables are divided into five categories using the natural breaks (Jenks)), $n$ is the number of counties explored in this study, $n_{i}$ is the number of samples in the sub-category after the independent variables are classified, $\sigma^{2}$ is the variance of the distribution of all high-tech firm samples, $\sigma_{i}^{2}$ is the variance of the samples in the sub-category after the independent variables are classified, and $q$ ranges from $(0,1)$. A larger value of $q$ represents a higher impact intensity.

\section{Results}

\subsection{The Spatial Pattern and Spatial Correlation of High-Tech Firms in the PRD}

The spatial distribution characteristics and the hotspots of high-tech firms in the PRD are investigated using the KDE method. Results from KDE analysis is shown in Figure 5, which reveal a significant clustering trend. Specifically, most of the firms are concentrated in Tianhe and Yuexiu districts in Guangzhou and in Nanshan and Futian districts in Shenzhen. Two significant distribution cores are observed in Guangzhou and Shenzhen, respectively (Figure 5a). There are 7216 high-tech firms in Guangzhou and Shenzhen, which account for $57.65 \%$ of all the high-tech firms in the study area. We further calculated the global Moran's I index, which characterizes the spatial autocorrelation and strength. The global Moran's I index for the density of a county-level high-tech firm is 0.1511 $(p=0.0000 ; \mathrm{z}=6.2066)$. This value indicates that there exists a significant spatial autocorrelation. The result is consistent with the findings of a large number of studies $[18,25,30]$. These studies have found out that innovation tends to be more concentrated than traditional production or manufacturing activities across and within a city and metropolitan area. In part, it is attributed to the need for setting up clusters in the early phase of innovation activities associated with research, design, and testing of new products. 
a

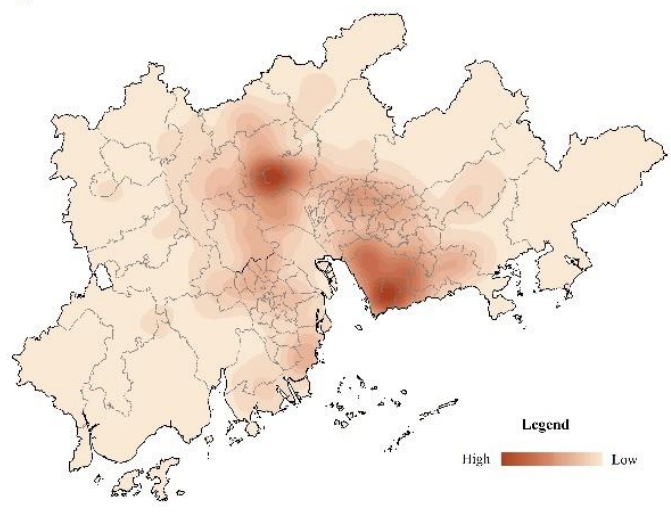

b

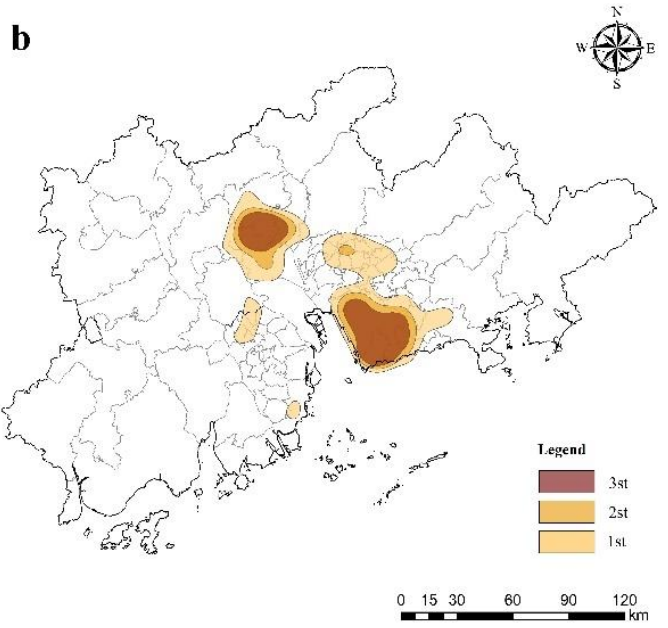

Figure 5. The spatial pattern of high-tech firms in the Pearl River Delta (PRD).

To sketch the true technology "core," we used the positive standard deviation values to examine the tail values of the high-tech firms' density surface (Figure 5b) [57]. As shown in Table 2, the area delineated by the first standard deviation curve (1st) is primarily the core area of Guangzhou, Shenzhen, and Dongguan. While the total area of these regions only accounts for $9.72 \%$ of the entire study area, $63.76 \%$ of the firms are concentrated in this region. The density of firms in this region is 6.57 times that of the entire study area. Furthermore, the area delineated by the third standard deviation curve (3st) only constitutes $2.99 \%$ of the total study area but hosts $35.34 \%$ firms. The density in this region is 11.8 times that of the entire study area. These results reveal a highly uneven distribution of the high-tech firms in the PRD, and most firms are concentrated in a few areas.

Table 2. The distribution characteristic of high-tech firms in regions with standard deviations.

\begin{tabular}{cccccc}
\hline & Area $\left.\mathbf{( k m}^{\mathbf{2}}\right)$ & Area Ratio (\%) & $\begin{array}{c}\text { Firm Count } \\
\text { (activities) }\end{array}$ & Proportion (\%) & $\begin{array}{c}\text { Count Density } \\
\text { (activities/ } \mathbf{k m}^{\mathbf{2}} \text { ) }\end{array}$ \\
\hline Study area & 41711 & 100 & 12516 & 100.00 & 0.30 \\
1st & 4055.68 & 9.72 & 7980 & 63.76 & 1.97 \\
2nd & 1890.63 & 4.53 & 5559 & 44.42 & 2.94 \\
3rd & 1248.57 & 2.99 & 4423 & 35.34 & 3.54 \\
\hline
\end{tabular}

\subsection{The Effects of Built Environment on the Location Choice and Agglomeration of High-Tech Firms}

To understand the influence of built environment on the agglomeration of high-tech firms, it is necessary to analyze the mechanism of how and to what extent the built environment factors affect the location choice of high-tech firms. Currently, literature on location selection for firms considers regression analysis to be the most effective method, and hence it is most widely used in these studies. Among these methods, the OLS method assumes a linear relationship between the independent and dependent variables. Since it is easy to define the variables, the OLS method is often used to estimate the intensity and direction of the impact of the variable. However, OLS cannot consider the spatial spillover effects between the units explored in the study. On the contrary, the spatial regression model takes the spatial autocorrelation effect of variables into consideration when performing the analysis. Therefore, the spatial regression model is selected to estimate the impact of the built environment factors. Simultaneously, we also obtained another set of results using the OLS method to find a more accurate regression estimation result. The results from the three different regression models (OLS, SLM, and SEM) are summarized in Table 3. 
Table 3. Estimation results of the regression models.

\begin{tabular}{|c|c|c|c|c|}
\hline & Coefficient & Std. Error & t/z-Value & $p$ \\
\hline \multicolumn{5}{|l|}{ OLS model } \\
\hline Intercept & 0.0497 & 0.7237 & 0.0686 & 0.9454 \\
\hline LSL & $0.0235^{* * *}$ & 0.0088 & 2.6818 & 0.0087 \\
\hline PSL & $-0.5256^{* * *}$ & 0.1096 & -4.7978 & 0.0000 \\
\hline TSL & $0.3257^{* * *}$ & 0.0641 & 5.0831 & 0.0000 \\
\hline TIL & $0.0940^{* * *}$ & 0.0280 & 3.3548 & 0.0012 \\
\hline NEL & -0.0138 & 0.0144 & -0.9565 & 0.3414 \\
\hline EL & 0.0000 & 0.0000 & 1.1118 & 0.2693 \\
\hline WL & 0.0000 & 0.0000 & -0.4064 & 0.6855 \\
\hline $\mathrm{HC}$ & $9.5465^{* * *}$ & 2.4047 & 3.9699 & 0.0002 \\
\hline \multicolumn{5}{|c|}{ R-squared: 0.8546; AIC: 107.425} \\
\hline \multicolumn{5}{|c|}{ Spatial lag model } \\
\hline W & 0.2690 & 0.0935 & 2.8758 & 0.0040 \\
\hline Intercept & -0.0004 & 0.6644 & -0.0006 & 0.9995 \\
\hline LSL $^{1}$ & $0.0211 * * *$ & 0.0081 & 2.6000 & 0.0093 \\
\hline PSL & $-0.4858^{* * *}$ & 0.1034 & -4.6999 & 0.0000 \\
\hline TSL & $0.3040 * * *$ & 0.0605 & 5.0268 & 0.0000 \\
\hline TIL & $0.0742^{* * *}$ & 0.0265 & 2.7969 & 0.0052 \\
\hline NEL & -0.0061 & 0.0134 & -0.4553 & 0.6489 \\
\hline EL & 0.0000 & 0.0000 & 1.3825 & 0.1668 \\
\hline WL & 0.0000 & 0.0000 & -1.0982 & 0.2721 \\
\hline $\mathrm{HC}$ & $9.0059 * * *$ & 2.2098 & 4.0755 & 0.0001 \\
\hline \multicolumn{5}{|c|}{ R-squared: 0.865; AIC: 103.668} \\
\hline \multicolumn{5}{|c|}{ Spatial error model } \\
\hline Intercept & -0.3454 & 0.8469 & -0.4078 & 0.6834 \\
\hline LSL $^{1}$ & $0.0245^{* * *}$ & 0.0088 & 2.7926 & 0.0052 \\
\hline PSL & $-0.5420^{* * *}$ & 0.0996 & -5.4427 & 0.0000 \\
\hline TSL & $0.3436^{* * *}$ & 0.0600 & 5.7271 & 0.0000 \\
\hline TIL & $0.0858^{* * *}$ & 0.0293 & 2.9335 & 0.0034 \\
\hline NEL & -0.0054 & 0.0181 & -0.2976 & 0.7660 \\
\hline EL & 0.0000 & 0.0000 & 1.4238 & 0.1545 \\
\hline WL & 0.0000 & 0.0000 & -0.0668 & 0.9468 \\
\hline $\mathrm{HC}$ & $8.7956^{* * *}$ & 2.2890 & 3.8426 & 0.0001 \\
\hline LAMBDA & 0.3493 & 0.1329 & 2.6279 & 0.0086 \\
\hline
\end{tabular}

R-squared: 0.86515; AIC: 102.607

(Note: LSL: Living service level, PSL: Public service level, TSL: Technology support level, TIL: Transport infrastructure level, NEL: Natural environmental level, EL: Economic level, WL: Wage level, HC: Human capital)

Table 3 lists the relevant parameters of the models used in the three different regression methods. The R-squared of the OLS, SLM, and SEM models are $0.8546,0.8650$, and 0.8652 , respectively. These values show that the model used in the three different regression methods possess a strong explanatory power. By comparing the results of the Akaike information criterion (AIC) of the three methods, it is found that the AIC obtained from the OLS, SLM, and SEM methods is 107.425, 103.668, and 102.607 , respectively. With these model parameters, we found that the SEM method is more suitable for performing the analysis in this study.

The regression results of SEM revealed a significant relationship for only four, out of the five, built environment factors discussed in this study. These factors are LSL, PSL, TSL, and TIL. Among the urban fundamental factors, a significant relationship was only found for HC. The results from the model confirmed that the built environment is an important factor in determining the location for high-tech firms. LSL, TSL, and TIL were found to exhibit a positive impact, while PSL exhibited an inhibiting effect. Additionally, HC was also found to play a positive role. Based on the results from the 
spatial regression model, we further evaluated the difference in the impact intensity between different significant factors using the GD technique.

The value of the five significant impact factors were classified into five levels using the natural breaks (Jenks). The spatial distribution of these factors is shown in Figure 6. Based on the GD technique, we estimated the impact intensity of these five factors, as shown in Figure 7. By organizing these factors according to their impact intensity, we found TSL (0.6641) > HC (0.5745) > PSL (0.5198) > TIL (0.5159) > LSL (0.4497). This result shows that the TSL has the strongest impact intensity, among the built environment factors, and $\mathrm{HC}$ also has a relatively strong impact intensity, among the urban fundamental factors. However, the impacts of the TIL and LSL on the location selection of high-tech enterprises are less significant.

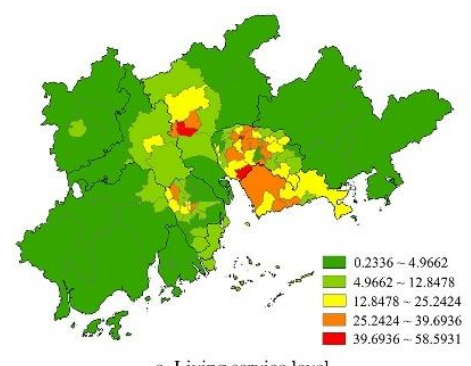

a. Living service level

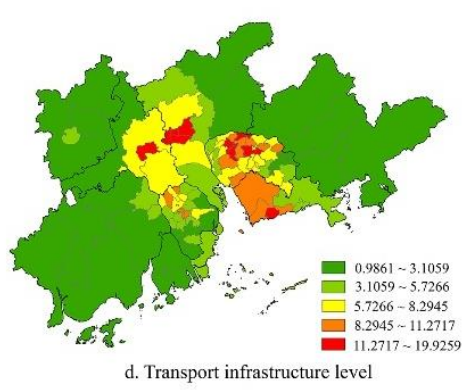

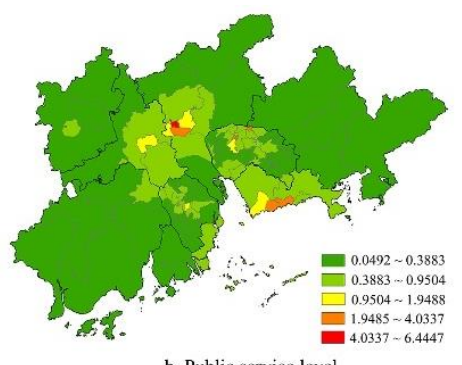

b. Public service level

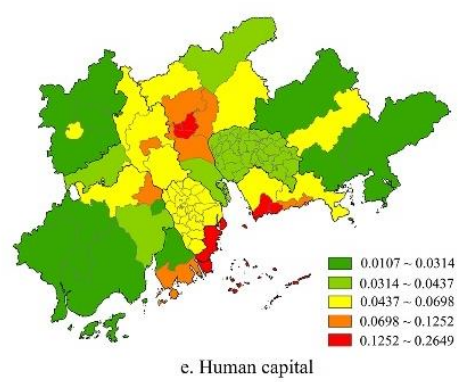

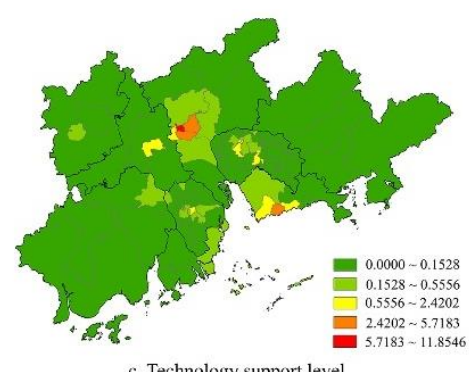

c. Technology support level

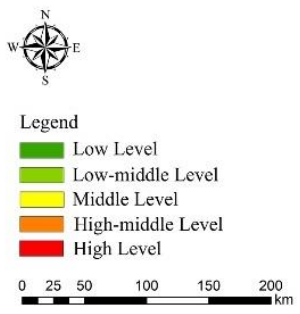

Figure 6. Map of the five impact factors in the Pearl River Delta.

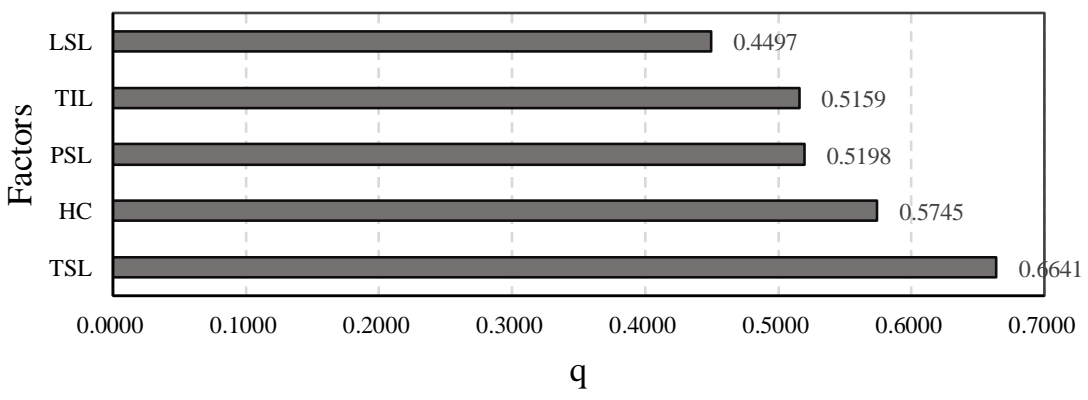

Figure 7. Power of the five impact factors in guiding the high-tech firms' distribution.

The results of the spatial regression model and GD technique reveal the mechanism of how built environment factors affect the location choice and the agglomeration of high-tech firms in the PRD. First, we found that the TSL has a considerable influence on the agglomeration of high-tech firms. The regression results show that the TSL has a significant positive impact on the spatial distribution of high-tech firms, with a q-value reaching 0.6641 . The impact intensity value of the TSL is the highest among all the built environment factors. Figure $6 c$ shows that the spatial distribution of the TSL is consistent with the agglomeration distribution of high-tech firms, where clustering cores are formed in the core regions of Guangzhou (Tianhe and Yuexiu districts) and Shenzhen (Nanshan and Futian districts). It is widely known that the factors supporting science and technology, such 
as universities and scientific research institutions, are the basis of innovation. Etzkowitz in his "triple helix model," theorized academia, state, and industry as the three main bodies that form the regional innovation system [63]. The significant influence of universities and research institutions on innovation is confirmed by many studies $[25,64-66]$. Hamidi examined and verified a significant positive correlation between university $R \& D$ and local innovation capabilities [42]. These studies found that R\&D investment and knowledge economy play a crucial role, and there is a potential causal relationship between these components and innovation. Our research shows that high-tech firms, being one of the main innovation subjects, prefer places with better scientific research foundations and neighborhoods with universities and research institutes when selecting their locations. The TSL is the most important built environment factor that shapes the spatial distribution pattern of high-tech firms in the PRD.

Second, the PSL was found to be negatively correlated with the spatial distribution of high-tech firms. The GD technique shows the q-value of the PSL to be 0.5198. This finding contradicts our presupposition. The public service level plays an important role in creating knowledge districts and attracting knowledge workers, which has been reflected in a large number of empirical studies [67-69]. However, in the PRD, we have not observed this relationship. A possible explanation is related to the background of the development of the PRD. In its early stages of development, the PRD achieved economic growth by engaging in the GPN as a "world factory." At this time, its industrial structure was at a lower end. With new development understanding from the Central Government and the transformation of the global economy, the PRD gradually adopted innovation as the mainstream concept of its development. Therefore, many developing zones and high-tech industrial parks are located in the periphery of cities or new urban areas [70,71]. These regions are also the hubs of high-tech firms. Few high-tech firms are distributed in the old city area with a high public service level. The development of high-tech industries is not in sync with infrastructural development in industrial zones, as shown in previous empirical studies $[70,71]$. Therefore, our modeling results reveal a negative relationship between the PSL and the agglomeration of high-tech firms.

Third, the results of the spatial regression model demonstrate a significant relationship between the TIL and the distribution of high-tech firms. The results obtained using GD technique also yield a relatively high q-value (0.5159). Similar findings were found in earlier studies, which revealed positive impacts of the TIL or accessibility condition on the agglomeration of high-technology firms and manufacturing companies $[29,72-74]$. Ye examined and verified a significant positive correlation between the new firms in the PRD and the transportation infrastructure [30]. Li explored the location factors of high-tech enterprises in Nanjing and also found high-tech enterprises tend to be concentrated in a location with high accessibility [29]. The TIL is always an important factor for determining the location of firms. Even with well-developed information and communication technology (ICT), in the contemporary world, high-tech firms still prefer locations with good accessibility conditions.

Fourth, the LSL also has a significant impact. The results showed a q-value of 0.4497 for the living service facilities. Our results indicated that the LSL can significantly promote the formation of innovative clusters, which is consistent with the findings of the same model presented in numerous studies $[75,76]$. These studies have shown that knowledge workers specifically consider the characteristics of a location and lifestyle choices when choosing a workplace. These choices can meet their complex requirements and creative identities, such as convenience facilities and the quality of business services. A high-quality living environment can attract more knowledge workers, which is the driving force for knowledge and innovation. [22,77]. The results of this research also showed that lifestyle convenience is positively correlated with the agglomeration of high-tech firms. In other words, high-tech firms prefer areas with good service facilities and better lifestyle convenience.

Fifth, the impact of the NEL is found to be insignificant. This finding also contradicts our presupposition. The natural environment is considered to be an important factor in attracting knowledge workers. A large number of studies confirmed this aspect $[78,79]$. They found that the improvement of the natural environment plays a crucial role in the construction of a knowledge 
district. A better natural environment is more attractive to the creative class. However, we did not find this connection in our empirical study. A possible reason is that a great quantity of high-tech firms in the PRD are concentrated in the science and technology development zones. During the transformation development stage of the PRD, the natural environment factor did not play a decisive role in determining the location of firms.

Sixth, this study calculates HC based on the proportion of the population who received higher education to the total population. Such value can directly reflect the distribution of high-quality talents in the PRD. As the results show (Table 3; Figure 7), there exists a significant positive correlation, with a q-value of 0.5745 , between $\mathrm{HC}$ and the agglomeration of high-tech firms. The influence intensity of HC on the distribution of high-tech firms is the second strongest only to the TSL. HC is one of the core factors in the development of innovation [80]. In the theory of regional innovation system, human capital is conceptualized as one of the basic conditions required for generating innovation, besides local culture and institutions [81]. Our findings are also consistent with the results of a large number of researches focused on human capital [82-85]. By reviewing the development of Shanghai's biotechnology industry, Zhang found that the accumulation of highly educated talents and Shanghai's talent policy significantly contributed toward promoting the development of the biotechnology industry in Shanghai's Zhangjiang town [86]. This study also found that the spatial distribution of HC shares a highly consistent trend with the distribution of high-tech firms (Figure 6). This finding confirms that $\mathrm{HC}$ is a key factor affecting the location choice of innovation activities.

\section{Discussion and Conclusions}

\subsection{Discussion}

The emergence of innovation and the location choice of high-tech firms have always been the two topics of interest in the field of economic geography and for economists. Particularly, both the hard and soft environments of a city are discussed in several studies. The hard environment of a city is usually conceptualized as factors that influence the location choice and agglomeration of firms. The soft environments, such as institutions and cultures, are often conceptualized as part of a regional innovation system that influences the generation of innovation. However, there is only limited research that provides a systematic discussion on the relationship between built environment and the location choices of innovation activities. Therefore, it would be necessary to refine the understanding of the influence mechanism of the built environment on the location choice and agglomeration of high-tech firms and elaborately discuss the impacts of heterogeneous built environment factors.

Based on the database of high-tech firms in the PRD in 2017, this study investigated how and to what extent the built environment factors affect the spatial agglomeration and location choice of high-tech firms. Using the spatial regression model and GD technique, we explained how different built environment factors affect the location choice and agglomeration of high-tech firms. Particularly, our study confirms the heterogeneity of the impacts of built environment factors on the agglomeration of high-tech companies in the local region. Several unique findings are also obtained from the studies.

First, the distribution of high-tech firms in the PRD was found to be highly concentrated spatially; the firms also exhibited a strong spatial dependence at an administrative level. In general, the high-tech firms formed two cluster centers at Guangzhou and Shenzhen, respectively, at the regional level. Most high-tech firms are distributed along the east and west sides of the Pearl River estuary. This pattern is consistent with the pattern of the city's administrative level in the PRD city agglomeration. Additionally, the results obtained by Moran's I index revealed a significant spatial autocorrelation pattern.

Furthermore, we found that the built environment has a significant impact on the location choice and agglomeration of high-tech enterprises. However, the impact of different built environment factors differs from each other. Among all the built environment factors, the technology support level exhibits the strongest impact, which has also been confirmed in previous studies. This factor is crucial to fostering regional innovation capacity, promoting the development of regional high-technology 
industries, strengthening the construction of a regional innovation environment, and improving science and technology support. Particularly, universities and research institutes play an irreplaceable role in the output of original scientific research and in the development of the local innovation atmosphere. The local governments should have an in-depth understanding of this fact and develop appropriate plans to support the local technology development environments. The TIL and LSL also play a significant positive role. A well-developed local transportation infrastructure significantly influences the location choices of high-tech firms. In the PRD, a high-quality infrastructure would reduce startup costs and attract employees. Similarly, the LSL plays a crucial role in improving the location's quality. Place and lifestyle are considered important factors in cultivating, attracting, and retaining the creative class. Therefore, to attract innovation activities in the local region and to cultivate the local innovation capacity, the local governments must optimize and improve the built environment in terms of the TIL and LSL.

Third, while the PSL is assumed to be a factor that improves the agglomeration of high-tech firms, our study shows a negative correlation between the PSL and agglomeration of high-tech firms. In the PRD, a higher quality PSL usually means a reduction in land supply and an increase in land prices. The well-developed old districts in the city have a higher PSL, while a large number of high-tech enterprises are established in the high technology industrial parks located outside the city or in the suburbs. This finding suggests that there is a mismatch between the spatial distribution of the PSL and the agglomeration of high-tech firms in the PRD. Government agencies should recognize this problem and formulate appropriate plans to balance the demand for better public services brought by the agglomeration of high-tech firms. Additionally, no significant correlation was found for the NEL. This finding indicates that, for local regions in the PRD, the quality of natural environment does not play a major role in promoting innovation. However, the local governments still cannot ignore the importance of improving the quality of the natural environment for attracting knowledge workers.

Finally, it is widely recognized that local economic development and salary levels have a major impact on the location choice of firms. However, our research confirms that there is no significant impact of these levels on high-tech firms. For example, when determining the location of a high-tech firm, a high-tech industrial park located in the suburbs of the city may be preferred to the old city area with a better economic condition. A high-tech industrial park allows high-tech firms to make better use of policy incentives to reduce the startup cost and, simultaneously, enjoy better HC benefits brought by the agglomeration of innovation. The HC factor was found to play a crucial role in our study. The impact of $\mathrm{HC}$ on the high-tech firms is the second strongest only to the local technology support level.

\subsection{Policy Implications}

Currently, academics and policymakers are posed with the question of how to achieve sustainable development in the region. As mentioned in "Transforming our world: The 2030 Agenda for Sustainable Development," "innovation" is already an important aspect of achieving regional sustainable development. Our findings from this study are of great significance to policymakers. For the local governments of the PRD, "innovation-driven" is the key to solving the sustainable development issues emerging from the traditional low value-added development model. Hence, the "innovation transformation" of the regional economic model is crucial. It is necessary to recognize the heterogeneous impacts of different built environment factors on the innovation agglomeration. When formulating local innovation and development policies, the local government should not only emphasize the construction of innovation networks and the cultivation of innovation clusters but also fully consider the importance of the built environment factors. Whether in the field of urban renewal or the cultivation of innovation district, the "innovative built environment" should be a key consideration.

Notably, from the managerial perspective, it is important to recognize that the influence of built environment factors on the distribution of innovation clusters is heterogeneous. Among them, the influence of the TSL is the strongest. In urban fundamental factors, the influence intensity of HC is only second to the TSL. The managerial policy for innovation should focus on the creation of an environment 
that supports local scientific and technological development; it should also propose more measures to attract human capital to cultivate local innovation capabilities. In summary, the formulation of a more comprehensive set of policies and planning framework from the perspectives of both soft and hard environments can enable the local regions to gain new advantages in their development process and transform themselves to accommodate a sustainable development model.

\subsection{Conclusions}

By empirically examining the relationship between the location choice of high-tech firms and the built environment of the PRD, this study established a more systematic concept framework for the built environment and proposed a built environmental indicator system, based on the innovation perspective. This study divides the built environment elements into five aspects, namely living, service, perceptual, industrial, and physical aspects. Further, we examined the relationship between built environment and high-tech firms using spatial regression and the GD technique. We found that the built environment has a significant impact on the agglomeration of high-tech firms.

The impact of built environment factors is also heterogeneous. Among all the built environment factors, the TSL has the greatest impact intensity on the location choice of high-tech firms, followed by the PSL, TIL, and LSL; the NEL is not significant in our empirical research. Conversely, concerning the urban fundamental factors, HC is a crucial factor in the agglomeration of high-tech firms, and its impact intensity is second only to the TSL. As a typical export-oriented economic zone in China, the PRD adopted the "world factory" development model and gradually shifted to the "innovation-driven" model. Innovation and sustainability are the key focus areas of the mainstream discourse. In addition to focusing on the cultivation of innovation networks, this study proposes that, under an innovation framework, the improvement of the built environment should become a part of future policy efforts.

\subsection{Limitations and Future Research}

From a methodological perspective, this study highlights the prospects of spatial analysis techniques and GD techniques in understanding the factors that influence the distribution of innovation elements. However, these methods also have shortcomings. Although the direction and intensity of the factors can be demonstrated at a global level, the influencing factors may have spatial heterogeneity. The methodology adopted in this study fails to reveal the impact at a local level and the existence of the spatial heterogeneity, which is also the focus of our future research.

From the perspective of datasets, the data used in this study only includes SMEs, and hence the findings are not applicable to the location choice of large technology companies. Moreover, it is important to mention that this study focuses on the impact of built environment factors on the location choice of high-tech firms. The choice of control variables is based on urban fundamentals because we mainly focus on a wide range of economic, social, and environmental factors outside the firms. However, we do not discuss endogenous factors such as firm size, corporate governance, and market factors. These factors also have an important impact on company performance. Therefore, a discussion on endogenous factors of an enterprise must form one of the focuses of in-depth research in the future.

Author Contributions: Conceptualization, K.W. and Y.W.; methodology, K.W.; formal analysis, K.W., Y.W. and Y.Y.; writing-original draft preparation, K.W. and Y.W.; writing-review and editing, K.W., H.Z. and G.H.; visualization, K.W.

Funding: This research was funded by Open Fund of Guangdong Provincial Key Laboratory of Urbanization and Geo-simulation (2018-02), the National Natural Science Foundation of China (No. 41871150, 41671128 and 41671130); GDAS' Project of Science and Technology Development (2016GDASRC-0101, 2017GDASCX-0806).

Conflicts of Interest: The authors declare no conflicts of interest.

\section{References}

1. Liu, H.; Leng, S.; He, C.; Peng, J.; Piao, S.; Wang, X. China's road towards sustainable development: Geography bridges science and solution. Prog. Phys. Geogr. 2019. [CrossRef] 
2. Brito, L.; Fisk, D.; Abreu, A.; Pan, J.; Dehgan, A.; Kabat, P.; Duflo, E. Science for Sustainable Development. Science 2012, 336, 1396-1398. [CrossRef] [PubMed]

3. Truffer, B.; Coenen, L. Environmental Innovation and Sustainability Transitions in Regional Studies. Reg. Stud. 2012, 46, 1-21. [CrossRef]

4. Vojnovic, I. Urban sustainability: Research, politics, policy and practice. Cities 2014, 41, S30-S44. [CrossRef]

5. Hansen, T.; Coenen, L. The geography of sustainability transitions: Review, synthesis and reflections on an emergent research field. Environ. Innov. Soc. Transit. 2015, 17, 92-109. [CrossRef]

6. Capello, R. Towards a New Conceptualization of Innovation in Space: Territorial Patterns of Innovation. Int. J. Urban Reg. Res. 2017, 41, 976-996. [CrossRef]

7. Ponsiglione, C.; Quinto, I.; Zollo, G. Regional Innovation Systems as Complex Adaptive Systems: The Case of Lagging European Regions. Sustainability 2018, 10. [CrossRef]

8. Yang, C. State-led technological innovation of domestic firms in Shenzhen, China: Evidence from liquid crystal display (LCD) industry. Cities 2014, 38, 1-10. [CrossRef]

9. Zhang, F. Building Biotech in Shanghai: A Perspective of Regional Innovation System. Eur. Plan. Stud. 2015, 23, 2062-2078. [CrossRef]

10. Miorner, J.; Zukauskaite, E.; Trippl, M.; Moodysson, J. Creating institutional preconditions for knowledge flows in cross-border regions. Environ. Plan. C Politics Space 2018, 36, 201-218. [CrossRef]

11. Yang, C. Restructuring the export-oriented industrialization in the Pearl River Delta, China: Institutional evolution and emerging tension. Appl. Geogr. 2012, 32, 143-157. [CrossRef]

12. Yang, C. From Strategic Coupling to Recoupling and Decoupling: Restructuring Global Production Networks and Regional Evolution in China. Eur. Plan. Stud. 2013, 21, 1046-1063. [CrossRef]

13. Schumpeter, J.A. Capitalism, Socialism, and Democracy; Allen and Unwin: London, UK, 1934.

14. Schumpeter, J.A. The Theory of Economic Development: An Inquiry into Profits, Capital, Credit, Interest, and the Business Cycle; Harvard University Press: Cambridge, MA, USA, 1934.

15. Mowery, D.C.; Rosenberg, N. Technology and the Pursuit of Economic Growth; Cambridge University Press: Cambridge, UK, 1991.

16. Grossman, G.M.; Helpma, E. Innovation and Growth in the Global Economy; MIT Press: Cambridge, MA, USA, 1993.

17. Scott, A.; Storper, M. Regions, Globalization, Development. Reg. Stud. 2003, 37, 579-593. [CrossRef]

18. Florida, R.; Adler, P.; Mellander, C. The city as innovation machine. Reg. Stud. 2017, 51, 86-96. [CrossRef]

19. Carlino, G.A.; Kerr, W.R. Agglomeration and Innovation. In Handbook of Regional and Urban Economics; Elsevier: Amsterdam, The Netherlands, 2015; Volume 5.

20. Feldman, M.P.; Florida, R. The Geographic Sources of Innovation: Technological Infrastructure and Product Innovation in the United States. Ann. Assoc. Am. Geogr. 1994, 84, 210-229. [CrossRef]

21. Feldman, M.P.; Kogler, D.F. Chapter 8-Stylized Facts in the Geography of Innovation. In Handbook of the Economics of Innovation; Hall, B.H., Rosenberg, N., Eds.; North-Holland: The Netherlands, 2010; Volume 1, pp. 381-410. Available online: https://www.sciencedirect.com/science/article/pii/S0169721810010087 (accessed on 4 July 2019).

22. Esmaeilpoorarabi, N.; Yigitcanlar, T.; Guaralda, M. Place quality in innovation clusters: An empirical analysis of global best practices from Singapore, Helsinki, New York, and Sydney. Cities 2018, 74, 156-168. [CrossRef]

23. Esmaeilpoorarabi, N.; Yigitcanlar, T.; Guaralda, M.; Kamruzzaman, M. Does place quality matter for innovation districts? Determining the essential place characteristics from Brisbane's knowledge precincts. Land Use Policy 2018, 79, 734-747. [CrossRef]

24. Zhang, F.; Wu, F. Rethinking the city and innovation: A political economic view from China's biotech. Cities 2019, 85, 150-155. [CrossRef]

25. Adler, P.; Florida, R.; King, K.; Mellander, C. The city and high-tech startups: The spatial organization of Schumpeterian entrepreneurship. Cities 2019, 87, 121-130. [CrossRef]

26. Guzman, J.; Stern, S. Where is Silicon Valley? Science 2015, 347, 606-609. [CrossRef]

27. Kerr, W.R.; Kominers, S.D. Agglomerative forces and cluster shapes. Rev. Econ. Stat. 2015, 97, 877-899. [CrossRef]

28. Roger, H. The Dynamics of Industrial Location: The Firm the Factory and the Production System; John Wiley \& Sons: Chichester, UK, 1997. 
29. Li, Y.; Zhu, K. Spatial dependence and heterogeneity in the location processes of new high-tech firms in Nanjing, China. Pap. Reg. Sci. 2017, 96, 519-535. [CrossRef]

30. Ye, Y.; Wu, K.; Xie, Y.; Huang, G.; Wang, C.; Chen, J. How firm heterogeneity affects foreign direct investment location choice: Micro-evidence from new foreign manufacturing firms in the Pearl River Delta. Appl. Geogr. 2019, 106, 11-21. [CrossRef]

31. Rasciute, S.; Pentecost, E.; Ferrett, B. Firm heterogeneity in modelling foreign direct investment location decisions. Appl. Econ. 2014, 46, 1350-1360. [CrossRef]

32. Rasciute, S.; Downward, P. Explaining variability in the investment location choices of MNEs: An exploration of country, industry and firm effects. Int. Bus. Rev. 2017, 26, 605-613. [CrossRef]

33. Giroud, X.; Mueller, H.M. Corporate Governance, Product Market Competition, and Equity Prices. J. Financ. 2011, 66, 563-600. [CrossRef]

34. Li, Z.F. Mutual Monitoring and Agency Problems. SSRN Electron. J. 2014. [CrossRef]

35. Coles, J.L.; Li, Z.; Wang, A.Y. Industry Tournament Incentives. Rev. Financ. Stud. 2018, 31, 1418-1459. [CrossRef]

36. Li, Z.F.; Lin, S.; Sun, S.; Tucker, A. Risk-adjusted inside debt. Glob. Financ. J. 2018, 35, 12-42. [CrossRef]

37. Dang, C.; Li, Z.; Yang, C. Measuring firm size in empirical corporate finance. J. Bank. Financ. 2018, 86, 159-176. [CrossRef]

38. Wei, X.; Chen, W. How Does a Firm's Previous Social Network Position Affect Innovation? Evidence from Chinese Listed Companies. Sustainability 2019, 11. [CrossRef]

39. Dicken, P. 'Placing' Firms: Grounding the Debate on the 'Global' Corporation. In Remaking the Global Economy: Economic-Geographical Perspectives; Peck, J., Yeung, H.W.-C., Eds.; Sage: London, UK, 2003.

40. Huang, H.; Wei, Y.D. Spatial inequality of foreign direct investment in China: Institutional change, agglomeration economies, and market access. Appl. Geogr. 2016, 69, 99-111. [CrossRef]

41. Yeung, H.W.C.; Liu, W.D.; Dicken, P. Transnational corporations and network effects of a local manufacturing cluster in mobile telecommunications equipment in China. World Dev. 2006, 34, 520-540. [CrossRef]

42. Hamidi, S.; Zandiatashbar, A.; Bonakdar, A. The relationship between regional compactness and regional innovation capacity (RIC): Empirical evidence from a national study. Technol. Forecast. Soc. Chang. 2019, 142, 394-402. [CrossRef]

43. Hamidi, S.; Zandiatashbar, A. Does urban form matter for innovation productivity? A national multi-level study of the association between neighbourhood innovation capacity and urban sprawl. Urban Stud. 2018, 56, 1576-1594. [CrossRef]

44. Bettencourt, L.M.A.; Lobo, J.; Helbing, D.; Kuehnert, C.; West, G.B. Growth, innovation, scaling, and the pace of life in cities. Proc. Natl. Acad. Sci. USA 2007, 104, 7301-7306. [CrossRef] [PubMed]

45. Glaese, E.L. Entrepreneurship and the City; National Bureau of Economic Research (NBER): Cambridge, MA, USA, 2007.

46. Kiuru, J.; Inkinen, T. Predicting innovative growth and demand with proximate human capital: A case study of the Helsinki metropolitan area. Cities 2017, 64, 9-17. [CrossRef]

47. Lawton, P.; Murphy, E.; Redmond, D. Residential preferences of the 'creative class'? Cities 2013, 31, 47-56. [CrossRef]

48. Morais, P.; Migueis, V.L.; Camanho, A.S. Quality of Life Experienced by Human Capital: An Assessment of European Cities. Soc. Indic. Res. 2013, 110, 187-206. [CrossRef]

49. Yun, J.J.; Zhao, X.; Yigitcanlar, T.; Lee, D.; Ahn, H. Architectural Design and Open Innovation Symbiosis: Insights from Research Campuses, Manufacturing Systems, and Innovation Districts. Sustainability 2018, 10. [CrossRef]

50. Zhang, S.; Yuan, C.; Wang, Y. The Impact of Industry-University-Research Alliance Portfolio Diversity on Firm Innovation: Evidence from Chinese Manufacturing Firms. Sustainability 2019, 11. [CrossRef]

51. Yigitcanlar, T. Making Space and Place for the Knowledge Economy: Knowledge-Based Development of Australian Cities. Eur. Plan. Stud. 2010, 18, 1769-1786. [CrossRef]

52. Esmaeilpoorarabi, N.; Yigitcanlar, T.; Guaralda, M.; Kamruzzaman, M. Evaluating place quality in innovation districts: A Delphic hierarchy process approach. Land Use Policy 2018, 76, 471-486. [CrossRef]

53. Shearmur, R. Are cities the font of innovation? A critical review of the literature on cities and innovation. Cities 2012, 29, S9-S18. [CrossRef]

54. Zoltan, J.; Acs, N. Innovation and the Growth of Cities. Growth Chang. 2005, 36, 581-583. [CrossRef] 
55. Schoenberger, E.; Walker, R.A. Beyond exchange and agglomeration: Resource flows and city environments as wellsprings of urban growth. J. Econ. Geogr. 2017, 17, 935-958. [CrossRef]

56. Boschma, R.A.; Fritsch, M. Creative Class and Regional Growth: Empirical Evidence from Seven European Countries. Econ. Geogr. 2009, 85, 391-423. [CrossRef]

57. Yu, W.; Ai, T.; Shao, S. The analysis and delimitation of Central Business District using network kernel density estimation. J. Transp. Geogr. 2015, 45, 32-47. [CrossRef]

58. Tobler, W.R. A Computer Movie Simulating Urban Growth in the Detroit Region. Econ. Geogr. 1970, 46, 234-240. [CrossRef]

59. Wang, Y.; Wang, S.; Li, G.; Zhang, H.; Jin, L.; Su, Y.; Wu, K. Identifying the determinants of housing prices in China using spatial regression and the geographical detector technique. Appl. Geogr. 2017, 79, $26-36$. [CrossRef]

60. Wang, J.-F.; Li, X.-H.; Christakos, G.; Liao, Y.-L.; Zhang, T.; Gu, X.; Zheng, X.-Y. Geographical Detectors-Based Health Risk Assessment and its Application in the Neural Tube Defects Study of the Heshun Region, China. Int. J. Geogr. Inf. Sci. 2010, 24, 107-127. [CrossRef]

61. Wang, J.-F.; Zhang, T.-L.; Fu, B.-J. A measure of spatial stratified heterogeneity. Ecol. Indic. 2016, 67, $250-256$. [CrossRef]

62. Luo, W.; Jasiewicz, J.; Stepinski, T.; Wang, J.; Xu, C.; Cang, X. Spatial association between dissection density and environmental factors over the entire conterminous United States. Geophys. Res. Lett. 2016, 43, 692-700. [CrossRef]

63. Etzkowitz, H.; Leydesdorff, L. The dynamics of innovation: From National Systems and "Mode 2" to a Triple Helix of university-industry-government relations. Res. Policy 2000, 29, 109-123. [CrossRef]

64. Audretsch, D.B.; Feldman, M.P. R\&D spillovers and the geography of innovation and production. Am. Econ. Rev. 1996, 86, 630-640.

65. Furman, J.L.; Porter, M.E.; Stern, S. The determinants of national innovative capacity. Res. Policy 2002, 31, 899-933. [CrossRef]

66. Romijn, H.; Albaladejo, M. Determinants of innovation capability in small electronics and software firms in southeast England. Res. Policy 2002, 31, 1053-1067. [CrossRef]

67. Durmaz, S. Analyzing the Quality of Place: Creative Clusters in Soho and Beyoglu. J. Urban Des. 2015, 20, 93-124. [CrossRef]

68. Pancholi, S.; Yigitcanlar, T.; Guaralda, M. Place making facilitators of knowledge and innovation spaces: Insights from European best practices. Int. J. Knowl.-Based Dev. 2015, 6, 215-240. [CrossRef]

69. Frenkel, A.; Bendit, E.; Kaplan, S. Residential location choice of knowledge-workers: The role of amenities, workplace and lifestyle. Cities 2013, 35, 33-41. [CrossRef]

70. Huang, Z.; He, C.; Zhu, S. Do China's economic development zones improve land use efficiency? The effects of selection, factor accumulation and agglomeration. Landsc. Urban Plan. 2017, 162, 145-156. [CrossRef]

71. Zhang, J. Interjurisdictional competition for FDI: The case of China's “development zone fever". Reg. Sci. Urban Econ. 2011, 41, 145-159. [CrossRef]

72. Liu, W.D.; Dicken, P.; Yeung, H.W.C. New information and communication technologies and local clustering of firms: A case study of the Xingwang Industrial Park in Beijing. Urban Geogr. 2004, 25, 390-407. [CrossRef]

73. Chatman, D.G.; Noland, R.B.; Klein, N.J. Firm Births, Access to Transit, and Agglomeration in Portland, Oregon, and Dallas, Texas. Transp. Res. Rec. 2016, 2598, 1-10. [CrossRef]

74. Credit, K. Transit-oriented economic development: The impact of light rail on new business starts in the Phoenix, AZ Region, USA. Urban Stud. 2018, 55, 2838-2862. [CrossRef]

75. Florida, R. The Rise of the Creative Class—Revisited: Revised and Expanded; Basic Books: New York, NY, USA, 2014.

76. Nelson, A. Reshaping Metropolitan America: Trends and Opportunities to 2030; Island Press: Washington, DC, USA, 2013.

77. Lee, H.-K.; Kim, H.-B. Regional preferences for the living environment and mobility of researchers and general workers: The case of Korea. Ann. Reg. Sci. 2019, 62, 169-186. [CrossRef]

78. Van Winden, W.; van den Berg, L.; Pol, P. European cities in the knowledge economy: Towards a typology. Urban Stud. 2007, 44, 525-549. [CrossRef]

79. Ballas, D. What makes a 'happy city'? Cities 2013, 32, S39-S50. [CrossRef]

80. Florida, R. Bohemia and economic geography. J. Economic Geography. 2002, 1, 55-71. [CrossRef] 
81. Philip, C.; Kevin, M. The Associational Economy; Oxford University Press: Oxford, UK, 1998.

82. Bosma, N.; Sternberg, R. Entrepreneurship as an Urban Event? Empirical Evidence from European Cities. Reg. Stud. 2014, 48, 1016-1033. [CrossRef]

83. Hundt, C.; Sternberg, R. Explaining new firm creation in Europe from a spatial and time perspective: A multilevel analysis based upon data of individuals, regions and countries. Pap. Reg. Sci. 2016, 95, 223-257. [CrossRef]

84. Baycan, T.; Nijkamp, P.; Stough, R. Spatial Spillovers Revisited: Innovation, Human Capital and Local Dynamics. Int. J. Urban Reg. Res. 2017. [CrossRef]

85. Wyrwich, M.; Stuetzer, M.; Sternberg, R. Entrepreneurial role models, fear of failure, and institutional approval of entrepreneurship: A tale of two regions. Small Bus. Econ. 2016, 46, 467-492. [CrossRef]

86. Zhang, F.; Wu, F. "Fostering indigenous innovation capacities": The development of biotechnology in Shanghai's Zhangjiang high-tech park. Urban Geogr. 2012, 33, 728-755. [CrossRef]

(C) 2019 by the authors. Licensee MDPI, Basel, Switzerland. This article is an open access article distributed under the terms and conditions of the Creative Commons Attribution (CC BY) license (http://creativecommons.org/licenses/by/4.0/). 